Mohamed Tohamy

\title{
Translating Culture-Specific Items in Khairy Shalaby's "The Time-Travels of the Man Who Sold Pickles and Sweets": A Semiotic Approach
}

\author{
Mohamed Tohamy,
}

Faculty of Arts \& Humanities,

Suez Canal University

\section{Abstract}

Translating culture-specific items is recognized by translators and translation researchers as a problematic task, particularly when the translator is alien to the source culture. This study aims at analyzing culture-specific items in Cooperson's translation of Kairy Shalaby's /raḥalāt Palțoršagi Palḥalwagi/ (1991), as "The Time-Travels of the Man Who Sold Pickles and Sweets" (2010, 2016). An adapted version of Peirce's three-dimensional model for semiotranslation (Representamen, Object, and Interpretation), and Dalabastita's (1993) transformation processes (substitution, repetition, deletion, addition, and permutation) are used to analyze the selected extracts. The analysis is restricted to 10 extracts, containing 27 culture-specific items which are randomly selected from the first four chapters of the novel. These items are in colloquial Egyptian Arabic and carry cultural, historical, and environmental connotations. The results show that out of 27 culture-specific items, the translator fails to deliver the semiotic representation of 15 , which may result in the loss of some aspects of the meaning intended by the ST author. It has also been found that the transformation processes that are extensively used by the translator are addition and deletion. These two processes are used to compensate for the absence of a semiotically equivalent sign in the Target language.

Key words: Culture-specific items - Peirce's semiotic model Transformation processes - semiotranslation

تعتبر ترجمة المفردات الثقافية الخاصة و احدة من الإشكاليات التي يو اجهها المترجم و الباحث في

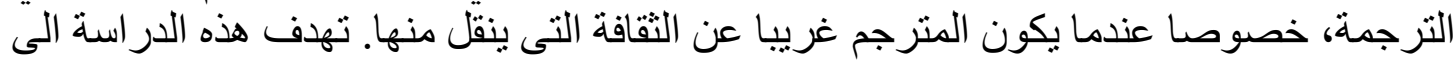

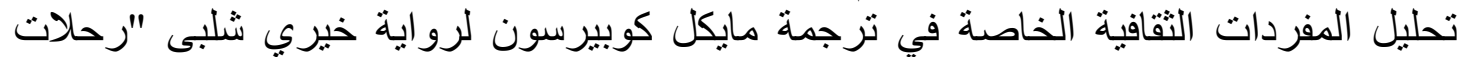

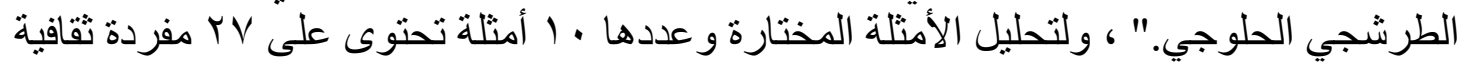

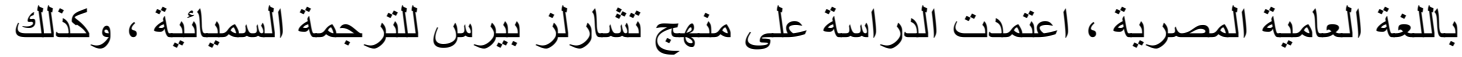

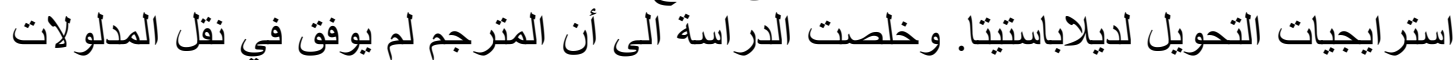

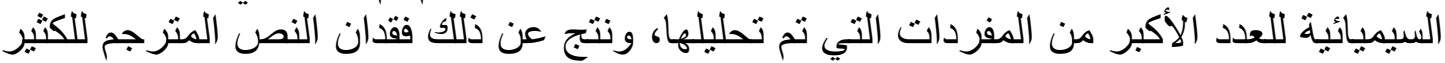

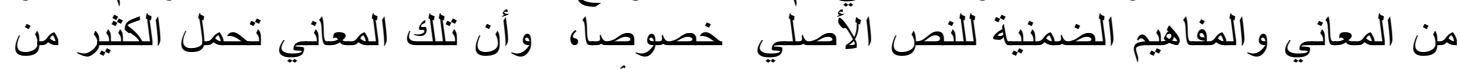

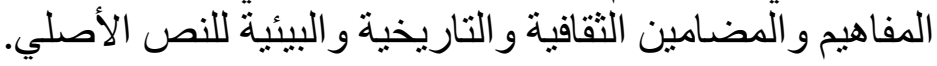


Translating Culture-Specific Items in Khairy Shalaby's "The Time-Travels of the Man Who Sold Pickles and Sweets": A Semiotic Approach

\title{
Translating Culture-Specific Items in Khairy Shalaby's "The Time-Travels of the Man Who Sold Pickles and Sweets": A Semiotic Approach
}

\section{Introduction}

\author{
Mohamed Tohamy, \\ Faculty of Arts \& Humanities, \\ Suez Canal University
}

The main objective of this study is to conduct a semiotic analysis of the translation of colloquial Egyptian Arabic items in Khairy Shalaby's novel "رحلات الطرشجي الحلوجي" /raḥalāt Palṭoršagi Palḥalwagi/ (1991), translated as "The Time-Travels of the Man Who Sold Pickles and Sweets" by Michael Cooperson. Translating colloquial Egyptian items/signs requires that the translator have thorough and deep understanding of Egyptian culture, especially those aspects that represent "a cultural gap or distance between the source language and the target language" (Newmark, 1988, p. 103). This study seeks to identify the extent to which the meanings of cultural signs/items are successfully transferred from the source language (i.e. Colloquial Egyptian Arabic; henceforth CEA) to the target language (i.e. English). To do this, the selected items are analyzed connotatively and denotatively in both the source and the target texts. By conducting a comparison between the SL and the TL, it is possible to find out how semiotic analysis helps to evaluate whether or not the translator could deliver the meanings and achieve the same effect that is intended by the author of the source text.

Translation is regarded by many researchers as a semiotic act which involves the transmission of a message from one semiotic system (conventionally known as source language), to another (target language) (Petrilli, 2013; Kowrdis, 2012; Bassnett, 1991). The term semiotranslation was introduced by Gorlee (1994) to highlight the close relationship between semiotics and translation. Torop (2008) argues that semiotranslation relies on the recognition that "culture works in many respects as a translation mechanism" (p. 257).

The connection between translation and culture is best identified when translation is approached from a semiotic perspective. Eco and Niggaard (2001) describe translation as "an intertextual and intercultural drift" (p. 218) which can be recognized as transmission of the 'a' text which is encoded according to a particular semiotic system to the 'b' text which is encoded according to another semiotic system. In addition, 


\section{Mohamed Tohamy}

Jakobson's (1959, p. 133) typology of translation as intralingual, interlingual, and intersemiotic is recognized by semioticians as an influential typology in the field of translation studies. Torop (2002, p. 593) points out the fact that semioticians adopt this typology as the base for understanding how cultural items/signs are translated from one semiotic system to another.

This study is based on Delabastita's (1993) definition of translation as " a kind of operation aiming... to transfer the meaning of an original text across linguistic and other borders" (p. xiii) (my emphasis). Delabastita's phrase "other borders" appeals to the Saussurian concept of meaning which distinguishes between denotation, or "the inherent semantic structure of a sentence", and interpretation or connotation which refers to understanding "the same sentence... in each unique case of language use", (Kooij, 1971, p. 117). The term interpretation, in this context, is related to Saussure's concept of non-linguistic semiotic systems.

Kordis (2015) mentions that semiotranslation studies include, among other topics, "the translation of connotation... [and]... the translation of semantic isotopies" (p. 315). Translation of connotations, according to Barthes (1967, p. 91), relate the cultural system included in the source language signs to the target language sign. Translation of semantic isotopies or, sense levels, enhances the concept that semiotic translation is, in fact, a translation of cultural signs.

\section{Literature Review}

Recent translation studies have shown an increasing tendency to bring together semiotics and translation theories. However, most of those studies focus on Jakobson's notion of intersemiotic translation showing how it is possible to translate from one semiotic system to another, such as "translating" a novel into a film. Such studies use the term translation metaphorically because it is extended to include a larger notion of translation than just translation from one natural language to another (Dusi, 2015). Perez-Gonzalez (2014, p. 120) comments on the lack of consensus on views regarding intersemiotic translation of literature. While some scholars such as Gottlieb (1997) and Remael (2001) regard intersemiotic translation as the transfer of meaning from one media system to another, others consider it a shift from one variant to another within the same sign system.

It is observed that studies that adopt a semiotic approach to analyze and evaluate translations are very few. Parlog (2019) refers to the fact that semiotic approaches to translation are "less studied than other fields of knowledge, such as linguistics, semantics, phonetics, translation studies, 
.... [i]t is paramount to the clarification of relations between different types of signs whose signification changes according to... significant elements involved in the process of constructing meaning" (p. 1). For example, Kurniasih, Nuriman, and Jaelani (2019) studied verbal-visual intersemiotic translation of advertisement slogans in Indonesian context. They investigate the translation of selected advertisement slogans from English into Indonesian, adopting Jackendoff's (1990) conceptual structure and Jakobson's (1959) intersemiotic translation approach. They find that the translation of verbal message from English into Indonesian has undergone various types of shifts, but the visual message remains the same.

Ali (2020) studies the translation of iconic language in the Holy Quran. He investigates how iconicity is rendered in Zidan's and Al-Hilali $\&$ Khan's translations of the Quran. Examining the cognitive processes associated with the semantic and semiotic representation of selected lexical items, Ali finds that the iconicity of the Quranic language conveys pragmatic and communicative meanings which represent a challenge to the translator.

It is worth mentioning that the scarcity of related literature gives more significance to the present study as it is one of the few studies that, so far, have adopted the Peircean three dimensional model to analyze the translation of cultural signs from CEA into English.

\section{Theoretical Framework}

This study is based on the Peircean perceptive on translation as developed by Torop (2008), Delabastita (2008) and Gorlee (2004). Peirce's model introduces the sign as having three constituents: the Interpretant, the Representamen and the Object. The Interpretant refers to ideas and meanings conveyed by the sign, or more precisely, it refers to the mental effect the sign has on its interpreters (Peirce, 1931-58). The other two components of Peirce's three-dimensional model are the sign itself, referred to as the representamen, and the object, the referent which is something the sign refers to.

In this Peircean model, the sign, or the representamen, comes first as it is the first element in the communication process that interpreters perceive before they start interpretation. The object comes in the second position "as it antecedes the sign as the knowledge which we have to interpret" ((Nöth, 2012, p. 28). The third position is occupied by the interpretant as it interprets the ideas carried by both the sign and the object. Ellström (2014, p. 91) considers the interpretant the most essential and "perhaps the most problematic" as it "comprises the notion of 
something being produced in the mind". It is the result of thinking and interpreting. Ellström (2014) uses Peirce's description of the interpretant as "a more developed new sign in the mind of some person" (p. 91).

The current study adopts the notion that the translated text is the interpretant as translation "depends on the interpretation of both individual sign and sign system" (Torop, 2000, p. 606). Thus, translation activity is the process of crossing the boundary between the original and the translation to reach the recipient culture (p. 599). To understand this activity, it is essential to analyze it in the light of Pierce's triad, where the interpretant is the result of translation activity, or a new developed sign placed within the recipient culture. This concept is shown in Figure 1, where the representamen (or the source text) is understood and processed by the translator who refers the sign to a referent (object/ background knowledge). This process results in a translated text carrying the mental effect the representamen has on the translator.

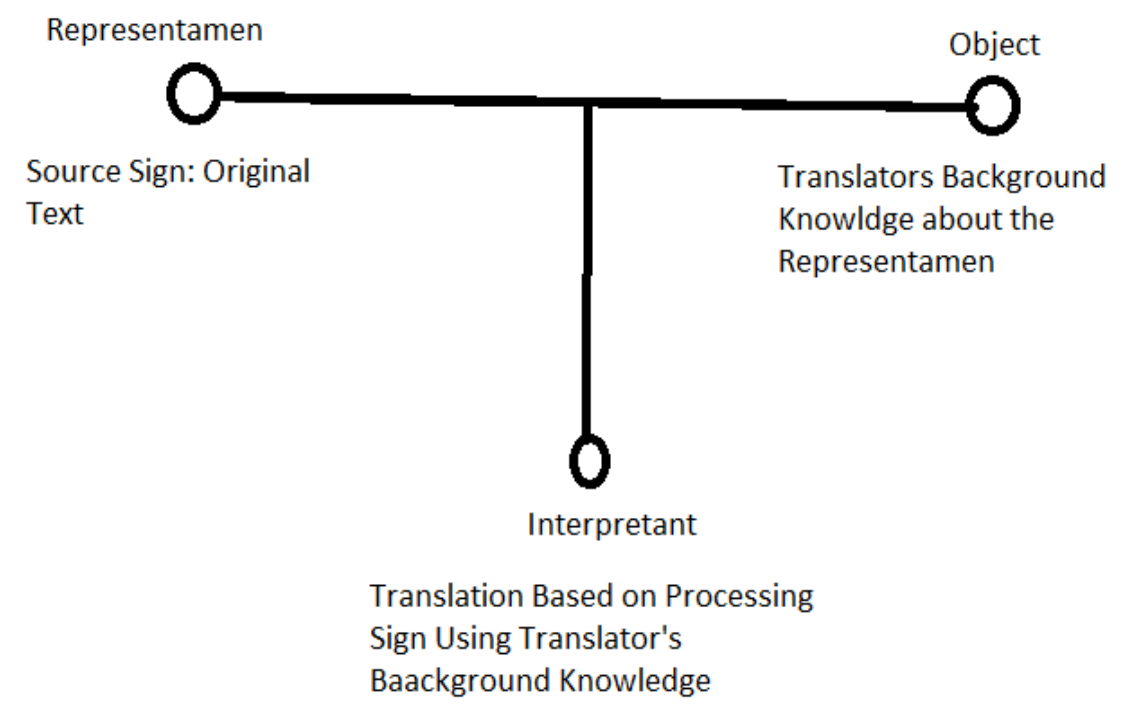

Fig. 1: Applying Peircean Model to the Translation Process

The journey of the sign from the representamen through the object to the interpretant passes one or more of the five transformation processes suggested by Delabastita (1993, pp. 33-39), namely substitution, repetition, deletion, addition, and permutation. Table 1 is Delabastita's configurations of those five processes in the light of source/target language code, source/target cultural code, and source/target textual code. 
Translating Culture-Specific Items in Khairy Shalaby's "The Time-Travels of the Man Who Sold Pickles and Sweets": A Semiotic Approach

Table 1: Transformation processes in translation (adapted from Delabastita, 1993)

\begin{tabular}{|c|c|c|c|}
\hline $\begin{array}{l}\text { Code } \\
\text { Operation }\end{array}$ & SL code $\rightarrow$ TL code & $\begin{array}{l}\mathrm{SL} \text { culture } \rightarrow \mathrm{TL} \\
\text { culture }\end{array}$ & $\begin{array}{l}\text { SL textual code } \rightarrow \\
\text { TL textual code }\end{array}$ \\
\hline Substitution & $\begin{array}{l}\text { higher or lower } \\
\text { degree of linguistic } \\
\text { equivalence }\end{array}$ & $\begin{array}{l}\text { - naturalization } \\
\text { - modernization } \\
\text { - topicalization } \\
\text { - nationalization }\end{array}$ & $\begin{array}{ll}\text { acceptable } & \text { text } \\
\text { adaptation } & \end{array}$ \\
\hline Repetition & $\begin{array}{l}\text { - total: non- } \\
\text { translation, copy } \\
\text { - partial: calque, } \\
\text { word-for-word } \\
\text { translation }\end{array}$ & - exoticization & non-acceptable text \\
\hline Deletion & $\begin{array}{l}- \\
\text { translation } \\
-\quad \text { expressive } \\
\text { reduction }\end{array}$ & $\begin{array}{l}\text { universalization } \\
\text { through the removal } \\
\text { of foreign cultural } \\
\text { signs }\end{array}$ & $\begin{array}{l}\text { - TT is a less } \\
\text { typical specimen of } \\
\text { a (target) text type } \\
\text { - neutralization of } \\
\text { stylistic } \\
\text { peculiarities }\end{array}$ \\
\hline Addition & $\begin{array}{l}\text { - paraphrase } \\
\text { - over translation } \\
\text { - } \quad \text { expressive } \\
\text { amplification }\end{array}$ & $\begin{array}{l}\text { exoticization through } \\
\text { the positive addition } \\
\text { of foreign cultural } \\
\text { signs }\end{array}$ & $\begin{array}{l}\text { TT is a more } \\
\text { typical specimen of } \\
\text { a (target) text type. }\end{array}$ \\
\hline Permutation & $\begin{array}{l}\text { metatextual } \\
\text { compensation }\end{array}$ & $\begin{array}{l}\text { metatextual } \\
\text { compensation }\end{array}$ & $\begin{array}{l}\text { metatextual } \\
\text { compensation }\end{array}$ \\
\hline
\end{tabular}

Table 1 shows that substitution, which is the replacement of an ST item by an equivalent TT one, represents the major relationship between the representamen and the interpretant (see Fig.1). Certain substitutions may achieve a higher degree of equivalence, but there are other cases where substitutions are "characterized by a ... less equivalent relational value" (Delabastita, 1993, p. 33). The second transformation category suggested by Delabastita is repetition where an item is "repeated or transferred directly from the ST into the TT". Siskin (1987, p. 310) puts repetition under the larger category of translation homologues. Examples of translation homologues are the adoption of loanwords into TL, and the spread of religious cultural items in specific languages through the translation of religious texts. The third component is deletion according to which an item in the ST "is not rendered in the TT" (p. 35). Deletions cannot be avoided as translators may find themselves obliged to sacrifice certain ST items for the sake of rendering a TT text with a maximal 
degree of cultural equivalence. As for addition, the TT contains linguistic, cultural, or textual signs which "have no apparent antecedent in the ST" (p. 36). Translators show a strong tendency to expand the TT for reasons of clarity and coherence.

The last component in Delabastita's five-point inventory is permutation, which refers to the "respective textual positions [of signs] within the ST and the TT" (p. 36). This means that the position of signs within the TT does not necessarily reflect their relative position in the ST. Permutation is shown at the metatextual levels where translators use footnotes, parentheses, bold fonts, or italics.

\section{Research Questions}

1 - To what extent does the translator succeed in delivering the semiotic representation of the original?

2- Does the cultural background of the translator affect his ability to transmit the cultural semiotic representation of the original?

\section{Data}

Khairy Shalaby (1938-2011) is an Egyptian novelist who is best known for portraying socially marginalized characters in his novels, short stories and plays. Shalaby's novel رحلات الطرشجي الحلوجي /raḥalāt Paltoršagi Palhalwagi/ (1991), and its translation as "The Time-Travels of the Man Who Sold Pickles and Sweets" by Michael Cooperson (2010) represent the data for this study. It is about a fictional time-traveler, named Ibn Shalaby, who wanders through time, moving from the 1990s to the Fatimd dynasty in the $12^{\text {th }}$ Century, the Mamluk era in the $14^{\text {th }}$ century, and back again to the 1990s.

The main feature of Khairy Shalaby's style, in his novels, is his ability to create a unique amalgam of Modern Standard Arabic (henceforth MSA) and CEA to form well-structured and coherent sentences. It may be true that Egyptian literary fiction contains stretches of CEA, especially in dialogues. However, Khairy Shalaby's writing is different in that he considers MSA and CEA two varieties of language that have to be equally appreciated and respected. In an interview that was published eleven years after his death, Shalaby admitted that he uses an artistic language with multiple levels of expression. The items which are commonly known as colloquial are considered by Shalaby as originally standard words that have undergone some phonological and sometimes semantic changes. When these items are used in Shalaby's novels, they are etymologically returned to their origin as standard words, and subjected to the rules of Arabic grammar and parsing (Aldostor, 2019). This phenomenon is illustrated in the following examples taken 
Translating Culture-Specific Items in Khairy Shalaby's "The Time-Travels of the Man

\section{Who Sold Pickles and Sweets": A Semiotic Approach}

from the novel under study. Words that are known as belonging to CEA are highlighted.

\section{Example 1:}

\begin{tabular}{|r|}
\hline (p. 20) يبذو أن المقريزي توسم في أني ابن ناس طيبين. (p) 16) \\
\hline He must have realized that I was a person of some importance. \\
\hline
\end{tabular}

\section{Example 2:}

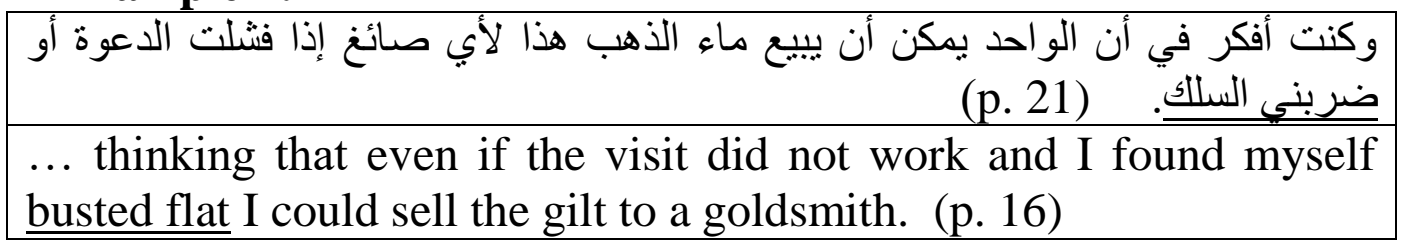

\section{Example 3:}

حرفوش مصري يجري ور ائي و لا يأنف من حمل البقجة على رأسه كالسيدات. (p. 45) The boy was a typical Egyptian harfush, not too proud to carry the bundle on his head as a woman would do. (p. 44)

Culture-specific concepts represented by the underlined items in examples 1, 2 and 3 may be challenging tasks for a non-native translator. Michael Cooperson, the translator of /rahalāt Palțoršagi Palḥalwagi/, is an American who studied Arabic in the department of Near Eastern Languages and Civilizations at Harvard University. As shown in his Curriculum Vitae (https://nelc.ucla.edu/person/michael-cooperson/), he just spent a couple of years in Cairo, a period which is too short for anyone to get acquainted with those culture-specific items that are deeply rooted in Egyptian culture. For these reasons, this study focuses on analyzing the translation of such items from a semiotic perspective. For consideration of space, 10 extracts, containing 27 culture-specific items, are randomly selected from the first four chapters of the novel to be analyzed using the Peircean model for translation analysis.

\section{Procedures}

The qualitative method is adopted for data analysis. CEA expressions in the selected extracts are focused on to find out whether or not the translator has successfully rendered these expressions into English. First, CEA expressions and their translations are decoded as signs based on the Peircean model. Second, these signs are identified according to the three-dimensional Peircean model as follows: 
- The Representamen: Source sign or the CEA form in the ST.

- The Object: Translator's background knowledge about the representamen.

- The Interpretant: Translation based on processing the sign using the translator's background knowledge.

The model consists of the linguistic sign (Representamen) which generates meanings based on translator's background knowledge (object) which, in turn, is significant to identify the meaning of the sign and deliver a translation (Interpretant) that can achieve appropriate semiotic equivalence between ST and TT. Semiotic equivalence means that the effect of the TT sign on the TL reader is somewhat similar to that the ST has on the SL reader. In this study, semiotic equivalence is investigated through analyzing the relationship between the Representamen and the Interpretant using Delabastita's (1993) five transformation processes: substitution, repetition, deletion, addition, and permutation. This relationship is examined in terms of the plus mathematical symbol (+) as a positive sign showing that the translator uses this specific transformation process in his translation of the item, and the minus symbol (-) to show that the transformation process is absent.

\section{Analysis}

Extract 1: Title

\begin{tabular}{|l|l|}
\hline ST & /rahalāt Paltoršagi Palhalwagi/ \\
\hline TT & The Time-Travels of the Man Who Sold Pickles and Sweets \\
\hline
\end{tabular}

\begin{tabular}{|c|c|c|c|c|c|c|}
\hline \multirow{2}{*}{$\begin{array}{l}\text { Representamen (ST sign) } \\
\text { رحلات الطرشجي الحلوجي } \\
\text { /rahalāt Palțoršagi } \\
\text { Palḥalwagi/ }\end{array}$} & \multicolumn{5}{|c|}{$\begin{array}{l}\text { Object: processing } \\
\text { representamen by translator }\end{array}$} & \multirow{2}{*}{$\begin{array}{l}\text { Interpretant (TT sign) } \\
\text { The Time-Travels of the } \\
\text { Man Who Sold Pickles } \\
\text { and Sweets }\end{array}$} \\
\hline & 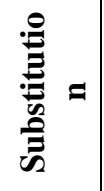 & & $\frac{\tilde{0}}{\frac{0}{0}}$ & : & ま & \\
\hline 1- rahalāt & + & - & - & + & - & time-travels \\
\hline 2- Palțoršagi & + & - & - & + & - & $\begin{array}{l}\text { the man who sold } \\
\text { pickles }\end{array}$ \\
\hline 3- Palḥalwagi & + & - & - & + & - & (who sold) sweets \\
\hline & \multicolumn{5}{|c|}{$\begin{array}{l}\text { Journeys of a man who } \\
\text { makes/sells pickles and sweets }\end{array}$} & \\
\hline
\end{tabular}


Translating Culture-Specific Items in Khairy Shalaby's "The Time-Travels of the Man

\section{Who Sold Pickles and Sweets": A Semiotic Approach}

The Arabic title of the novel carries a number of cultural semiotic implications. The title contains three signs (the terms "words", "signs" and "items" are used interchangeably), rahalāt, Palțoršagi, and Palhalwagi. The first sign rahalat trendered as time-travels refers to the act of moving from one location to another. However, the events of the novel show that this sign is intended by the author to refer to the protagonist's time dislocations. Ibn Shalaby's movements between different points in time are what the author, Khairy Shalaby, thought about when he used the sign rahalat in the title of his novel. Taking this into consideration, the translator renders it as time-travel, where the item time is added to achieve an interpretant which is equal to the representamen posed in the original. The second sign in the title, ?altoršagi, which was first used during the Fatimid Era in the $10^{\text {th }}$ century (Wassef, 2004, p. 904), refers to preserving vegetables in salt water and vinegar. Amin (2013) considers Paltoršagi a unique Egyptian phenomenon that he has not seen in other countries. Moreover, he notes that "the poor live on eating a lot of it" (p. 342). The translator does not render this word as a single noun like the original; rather, he translates it as a relative clause, the man who sold pickles. This means that the original sign is subjected to two transformation processes (namely substitution and addition) before it occurs as the interpretant the man who sold pickles. The translator follows the same strategy with the third sign in the title, Palhalwagi. However, to avoid repetition, he reduces the (bracketed) relative clause as follows:

The Time-Travels of the Man Who Sold Pickles and (who sold) Sweets

The title itself signifies a number of iconic connotations which can be stated as follows:

- Daily life of an ordinary Egyptian is a mixture of salt (pickles) and sweet.

- The history of Egypt contains days of victory and power (sweet), and others of defeat and weakness (pickles).

It is clear that Cooperson, who studies Near Eastern languages and civilizations, takes these connotations into consideration when he translates the title of this novel. Thus, semiotic equivalence between the Arabic title and its translation is highly achieved. 


\section{Extract 2:}

\begin{tabular}{|c|c|}
\hline ST & 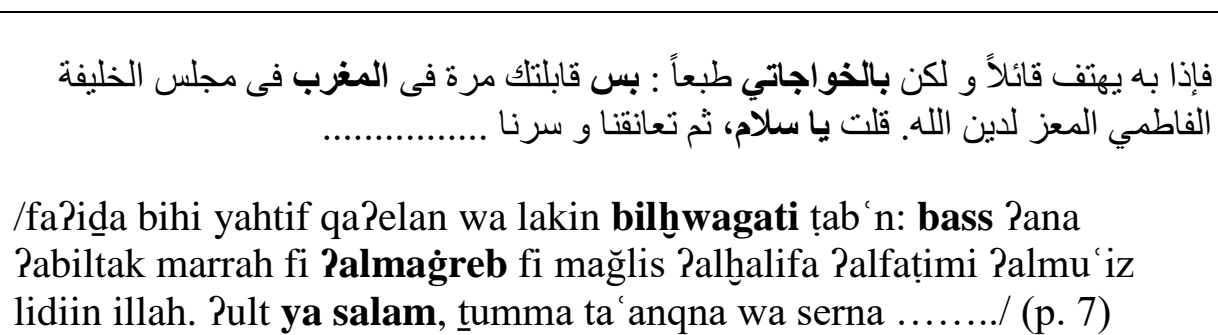 \\
\hline TT & $\begin{array}{l}\text { when he suddenly exclaimed (in Foreignish, naturally), "Got it! It was } \\
\text { in North Africa, at Mu'izz's court in Qayrawan." } \\
\text { "How about that!" I exclaimed. We embraced and set off ..... (p. 2) }\end{array}$ \\
\hline
\end{tabular}

\begin{tabular}{|c|c|c|c|c|c|c|}
\hline \multirow[t]{2}{*}{ Representamen (ST sign) } & \multicolumn{5}{|c|}{$\begin{array}{l}\text { Object: processing } \\
\text { representamen by translator }\end{array}$} & \multirow{2}{*}{\begin{tabular}{|l|}
$\begin{array}{l}\text { Interpretant (TT } \\
\text { sign) }\end{array}$ \\
\\
\end{tabular}} \\
\hline & 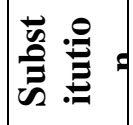 & 窇: & : & 章. & 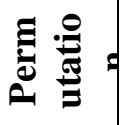 & \\
\hline 1- bilhwagati țab'n & + & - & - & + & + & $\begin{array}{l}\text { (in Foreignish, } \\
\text { naturally) }\end{array}$ \\
\hline 2- bass & + & - & - & + & + & Got it! \\
\hline 3- Palmaġreb & + & - & - & + & - & North Africa \\
\hline $\begin{array}{l}\text { 4- mağlis Palhalifa } \\
\text { Palfațimi Palmu iz } \\
\text { lidiin illah }\end{array}$ & + & - & + & + & - & $\begin{array}{l}\text { at Mu'izz's court in } \\
\text { Qayrawan }\end{array}$ \\
\hline 5- ya salam & + & - & - & + & + & "How about that!" \\
\hline & \multicolumn{5}{|c|}{$\begin{array}{l}\text { Non-Egyptian speaker is } \\
\text { involved-speaker has a } \\
\text { different culture - speaker } \\
\text { speaks Arabic with a European } \\
\text { accent. }\end{array}$} & \\
\hline
\end{tabular}

In this extract, the speaker, who is trying to remember where he met Ibn Shalaby, is non-Egyptian. The object of this extract shows that the "الخواجة " speaker has a different culture and does not speak Arabic. /alhawağah/ in the Egyptian culture is a sign that is used to refer to a Christian European who used to live and work in Egypt (Amin, 2013, p. 199). Because those foreigners need to interact with Egyptians in their daily transactions, they try hard to speak CEA. The translator adds the brackets ( ) in order to highlight the uniqueness of this word in CEA. He uses the brackets "(in Foreignish, naturally)" as supplementary information which can be removed without changing the structural flow of the sentence. Then, the writer continues the dialogue between the two men using the sign "بس" /bass/ which means "but" or "only". Egyptians 


\section{Who Sold Pickles and Sweets": A Semiotic Approach}

sometimes use "بس" as a filler which gives the speaker a chance to think of what he/she is trying to say. However, it is delivered in the TT through the meaning of the abbreviated sentence "Got it!", (its full form being is "I have got it!"), which can be back translated as "وجدتها، "وسو /wağdtuha/. The translator deals with the sign "بس" as an idiom in which he uses the permutation technique trying hard to deliver the meaning of this Egyptian filler. This means that the person finds what he is trying to remember.

The translation of "/almagrib/ into "North Africa" depends on the historical events of the Fatimid State which has been extended along the Mediterranean coast from Morocco to Egypt. These wide "مجلس الخليفة الفاطمي المعز لاين الله،، regions have been called North Africa. /mağlis Palhalifa Palfațimi Palmu'iz lidiin illah/ is translated into "Mu'izz's court in Qayrawan". This part contains many changes in the translated text. For instance, the phrase "الخليفة الفاطيه" /alhalifa alfatimi/ is not deleted in the TT. The translator just refers to the name of the caliph "Muizz" without mentioning his social rank in the Fatimid Era. The sign "Qayrawan" is not found in the source text. It is added as the regular place of the caliph at that time. The interpretation of this extract depends mainly on the historical background of the writer, the translator and the reader.

" "يا سلام6/ya salam/ is a sign of surprise. It is followed in the TT, but not in the ST, by the exclamation mark (!). It doesn't have any relation to the original meaning of the word "سملام" /salam/ which means "peace". The exclamation appears clearly from the rising tone which stresses the last syllable /yӘ sla:m/. The paralinguistic features such as pitch, sound quality and tone are substituted in the translation by inverted commas and exclamation mark: "How about that!".

Semiotically, the translator finds it difficult to deliver the meanings of culture-based items in this extract. However, he resorts to some strategies, particularly addition and permutation, to make the TT signs able to carry the ST cultural features as much as possible. For example, he finds a linguistic equivalent to the sign "بالخواجاتي/belhwagati/ which is "Foreignish" although this word is not included in the entries of many English/English dictionaries. This equivalent sign makes it easy for the readers of the target text to understand how this character is speaking. Besides, he does not mention the social rank of "Mu'izz" in this extract directly. He mentions it in the chapter's title "The Caliph's Invitation" "لدعوة للإفطار على مائدة المعز لاين الله الفاطي،؛ /da'wa lilPifțar 'ala maPidat 
Palmu'iz lidin illah Palfați/ which delivers the meaning appropriately. Additionally, his translation of the colloquial expression "يا سلام/ya slam/ is suitable for its original Egyptian meaning. The translator achieves the semiotic equivalence by adding the word "exclaimed" which adds to the meaning of the question "How about that!". On the other hand, he does not succeed in delivering the meaning of the sign "بس". Semiotic equivalence is not achieved here although he adds (!).

\section{Extract 3:}

\begin{tabular}{|c|l|}
\hline ST & خواجا أروب يعرف كل شيء ............... \\
\hline TT & $\begin{array}{l}\text { Lawağah Parub ya 'rif kul šay'/ (p. 8) } \\
\text { everything............. (p. 2) }\end{array}$ \\
\hline
\end{tabular}

\begin{tabular}{|c|c|c|c|c|c|c|}
\hline \multirow[t]{2}{*}{ Representamen (ST sign) } & \multicolumn{5}{|c|}{$\begin{array}{l}\text { Object: processing } \\
\text { representamen by translator }\end{array}$} & \multirow[t]{2}{*}{ Interpretant (TT sign) } \\
\hline & 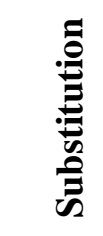 & 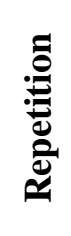 & $\frac{0}{.00}$ & & & \\
\hline \multirow[t]{2}{*}{ hawağah Parub } & + & - & - & + & - & wily foreign gentleman \\
\hline & \multicolumn{5}{|c|}{$\begin{array}{l}\text { Foreigners are clever, } \\
\text { knowledgeable, cunning, and } \\
\text { know what they want. }\end{array}$} & \\
\hline
\end{tabular}

This sign is interpreted as the person who is very clever at getting what he wants. The sign "الخواجة"/alhawağah/ is analyzed semiotically "أروب" " /Rarub/ is an adjective which is given to the person who knows different things in many fields. It is an iconic sign for the person's cleverness. The translator adds a compensated sign for "أروب" which is "wily". He also makes a paraphrastic translation for the sign to make it clearer. According to Oxford Advanced Learner's Dictionary (2005:1685), "wily" means "clever at getting what you want, and willing to trick people". Besides, "gentleman" is defined as "a man who is polite and well educated, who has excellent manners and always behave well" (p. 621). This sign is repeated three times in this chapter. It is also translated in the same way to deliver the same concept in the translator's mind. 


\section{Who Sold Pickles and Sweets": A Semiotic Approach}

Semiotically, the translator could not find a sign in the TT that is equivalent to the ST sign /Parub/. In Egyptian culture / Parub/ is not necessarily a gentleman, so the use of the word "gentleman" is redundant in this context.

\section{Extract 4:}

\begin{tabular}{|c|c|}
\hline ST & 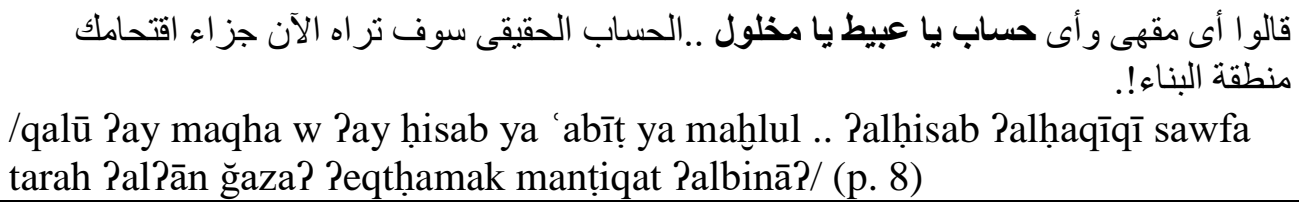 \\
\hline TT & $\begin{array}{l}\text { "Café?" they said. "Bill?" "The only thing you'll be paying is the penalty } \\
\text { for trespassing on a building site!" (p. 3) }\end{array}$ \\
\hline
\end{tabular}

\begin{tabular}{|c|c|c|c|c|c|c|}
\hline \multirow[t]{2}{*}{ Representamen (ST sign) } & \multicolumn{5}{|c|}{$\begin{array}{l}\text { Object: processing } \\
\text { representamen by translator }\end{array}$} & \multirow[t]{2}{*}{ Interpretant (TT sign) } \\
\hline & م & 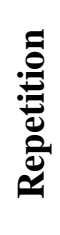 & $\frac{\tilde{0}}{\frac{0}{0}}$ & 窇 & 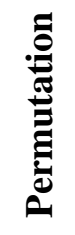 & \\
\hline \multirow{2}{*}{ 1- hisab } & + & - & - & - & - & \multirow{2}{*}{ bill } \\
\hline & \multicolumn{5}{|c|}{$\begin{array}{l}\text { Price for drinks in popular coffee } \\
\text { shops }\end{array}$} & \\
\hline \multirow{2}{*}{ 2- ya 'abīṭ } & - & - & - & - & - & \multirow[b]{2}{*}{ - } \\
\hline & \multicolumn{5}{|c|}{ foolish, stupid } & \\
\hline \multirow{3}{*}{ 3- ya mahlul } & - & - & - & - & - & \multirow[b]{2}{*}{ - } \\
\hline & \multicolumn{5}{|c|}{$\begin{array}{c}\text { crazy, suffering from mental } \\
\text { disorders }\end{array}$} & \\
\hline & \multicolumn{5}{|c|}{$\begin{array}{l}\text { Someone is described as being } \\
\text { foolish and crazy because they } \\
\text { interfere with others' affairs. }\end{array}$} & \\
\hline
\end{tabular}

Three forms of the representamen in this extract are omitted in the interpretant. That is why the ST signs / hisab/, /ya 'abitt/, and /ya mahlul/ are not represented in the TT. The first sign /hisab/ is used to mean "price for articles services". It is often used in popular coffee places to mean "price for drinks". Using the TT sign "bill" as translation of /hisab/ reduces the cultural semiotic connotation of the word. If the translator used the addition strategy and translated the word as "coffee price" rather 
than "bill", the TT sign would have achieved a higher level of cultural connotation.

The whole sentence is interpreted as that the speaker is annoyed of the foolish behaviour of the addressee. The signs / 'abit/, and /mahlul/ are used in CEA to describe someone who behaves in a foolish and stupid way. "عبيط" / 'abit t / is translated by Spiro (1991, p. 33) as "silly or foolish". This is an Egyptian adjective which describes a stupid person "مخلول" , /mahlul/, in Egyptian culture, refers to a crazy person who suffers from mental disorder. In fact, these two signs used in CEA to insult others, particularly those who cause annoyance by their misbehaviour. Unfortunately, the translator completely ignores these two words, which might make this particular situation confusing to the TT reader. It would be possible for the translator to use other linguistic signs such as "crazy or foolish" to deliver the intended meaning, but he did not; and this results in meaning loss in the translated texts. These signs can be put in the form of exclamations like "How crazy are you! /How foolish are you! /What a foolish guy! /". The translator fails to use any of the five transformation strategies to deliver these signs in the TT text. He uses the deliberate omission technique by the removal of these two semiotic cultural signs.

\section{Extract 5:}

\begin{tabular}{|c|c|}
\hline ST & 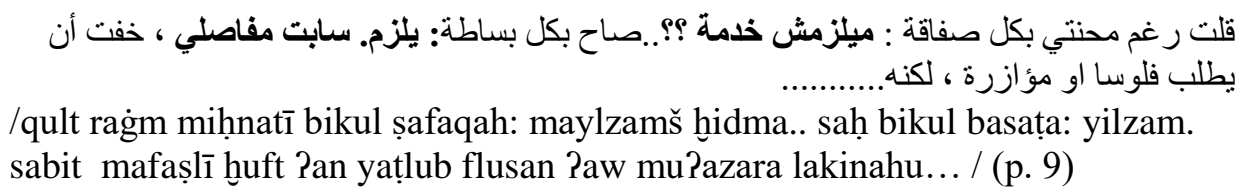 \\
\hline TT & $\begin{array}{l}\text { Despite my predicament, I had the effrontery to shout, "If you need any-thing, } \\
\text { just let me know!" } \\
\text { He called back, "Now that you mention it, I do." } \\
\text { My knees went weak... What if he needed money? Or someone to take his side } \\
\text { in the argument he was having?..........(p. 4) }\end{array}$ \\
\hline
\end{tabular}




\begin{tabular}{|c|c|c|c|c|c|c|}
\hline \multicolumn{7}{|c|}{$\begin{array}{l}\text { Translating Culture-Specific Items in Khairy Shalaby's "The Time-Travels of the Man } \\
\text { Who Sold Pickles and Sweets": A Semiotic Approach }\end{array}$} \\
\hline \multirow[t]{2}{*}{ Representamen (ST sign) } & \multicolumn{5}{|c|}{$\begin{array}{l}\text { Object: processing } \\
\text { representamen by translator }\end{array}$} & \multirow[t]{2}{*}{ Interpretant (TT sign) } \\
\hline & & 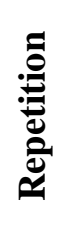 & $\frac{0}{0}$ & : & 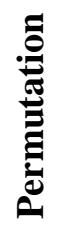 & \\
\hline \multirow{2}{*}{ maylzamš hidma } & + & - & - & + & - & \multirow{2}{*}{$\begin{array}{l}\text { If you need any-thing, } \\
\text { just let me know! }\end{array}$} \\
\hline & \multicolumn{5}{|c|}{ offering help } & \\
\hline \multirow{2}{*}{ yilzam } & + & - & - & + & - & \multirow{2}{*}{$\begin{array}{l}\text { Now that you mention } \\
\text { it, I do }\end{array}$} \\
\hline & \multicolumn{5}{|c|}{ accepting offer } & \\
\hline \multirow{3}{*}{ sabit mafașlī } & + & - & - & + & - & \multirow[b]{2}{*}{ My knees went weak } \\
\hline & \multicolumn{5}{|c|}{ having no potential to help } & \\
\hline & \multicolumn{5}{|c|}{$\begin{array}{l}\text { Offering help without having } \\
\text { the potential to be helpful }\end{array}$} & \\
\hline
\end{tabular}

This extract shows that someone is telling another that he needs something. However, the addressee feels that he is not prepared to offer help. The object of the whole extract can be interpreted as offering help to someone despite having no potential to be helpful. The object in this example, shown in the offer "ميلزمش خدمة" /maylzamš hidma/, reflects the magnanimity and the chivalry of ordinary middle-class Egyptians. The sign "خدمة"/hidma/ is not translated literally as "service". The translator deals with the connotation of this word "If you need anything". Besides, the answer to this offer is very concise in the TT "يلزم"/yilzam/ which shows the speaker's reluctance as to whether to accept the offer or not. It is rendered as a complete statement "Now that you mention it". The translator adds this clause in the interpretant to show the reluctance of the speaker in the representamen /yilzam/. This clause is followed by another simple clause "I do" which can be understood as "Yes, I need something".

The ST idiom "سابت مفاصلي" /sabit mafaṣlī/ is a very famous Egyptian idiom which expresses strong feelings of fear. The translator gives an equivalent idiom in the TT "My knees went weak" giving the same meaning. Cambridge Online Dictionary (https://dictionary.cambridge.org/dictionary/english/weak-at-theknees\#: :text=If\%20you\%20go\%20weak\%20at,go\%20weak\%20at\%20th 
e\%20knees.) defines this idiom as "lose your strength and feel you are going to fall over, usually because of... something unpleasant or frightening". Both ST and TT are iconic signs for the feeling of fear. This is one of the few examples in the novel where the ST idiom has an equivalent TT one.

Cooperson has successfully rendered the meaning of this extract. The interpretant delivers the meaning of the object related to Egyptian culture. A high level of semiotic cultural equivalence is achieved because the translator uses the transformation techniques, substitution and addition, appropriately to deliver the meaning intended by the ST author. He uses some target cultural signs which are relevant to the ST signs.

\section{Extract 6:}

\begin{tabular}{|c|c|}
\hline ST & 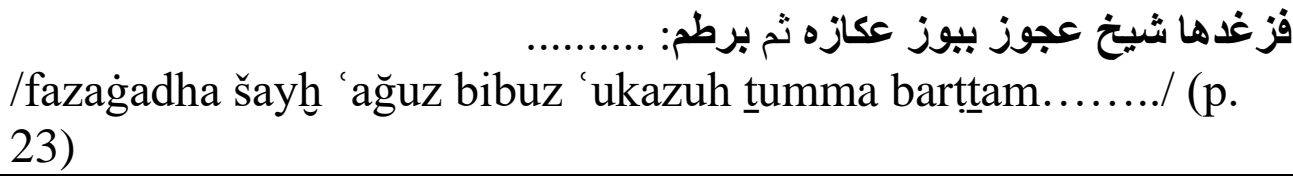 \\
\hline TT & $\begin{array}{l}\text { Poking at her with his staff, an old man launched into a } \\
\text { rant:...... (p. 18) }\end{array}$ \\
\hline
\end{tabular}

\begin{tabular}{|c|c|c|c|c|c|c|}
\hline \multirow[t]{2}{*}{ Representamen (ST sign) } & \multicolumn{5}{|c|}{$\begin{array}{l}\begin{array}{l}\text { Object: processing } \\
\text { representamen by } \\
\text { translator }\end{array} \\
\end{array}$} & \multirow[t]{2}{*}{ Interpretant (TT sign) } \\
\hline & 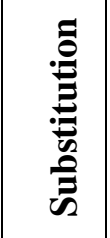 & 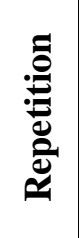 & 节 & 苞 & 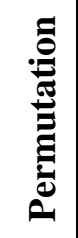 & \\
\hline 1- fazagiadha & + & - & - & - & - & Poking \\
\hline 2- šayh 'ağuz & + & - & + & - & - & an old man \\
\hline 3- bibuz & - & - & - & - & - & - \\
\hline \multirow[t]{2}{*}{ 4- barț̣am } & + & - & & & + & launched into a rant \\
\hline & \multicolumn{5}{|c|}{$\begin{array}{l}\text { An old man pokes a girl } \\
\text { with his walking stick and } \\
\text { starts to speak angrily. }\end{array}$} & \\
\hline
\end{tabular}




\section{Who Sold Pickles and Sweets": A Semiotic Approach}

This extract shows that someone pokes a girl with his staff and starts to rant. The old man is ranting about the Mamluks whom no one knows where they are from. The object explains this representamen as an old man who pokes a girl with his walking stick and starts to speak angrily. "פز غدها" /fazagiadha/ is a CEA expression which means poking someone physically with something. As a result, the meaning of this sign is delivered through the translator's ability to process the cultural references of the sign in his mind. The sign, "ثيخ عجوز" /šayh 'ağuz/ is symbolic of an old-aged man. It is translated as "an old man", which partially delivers the meaning, because in addition to old age, the Arabic sign /šayh/ refers to dignity and solemnity. This aspect of meaning is absent in the TT. Then, "بوز عكازه" /buz 'ukazuh/ is an iconic sign for the oldness of the man who cannot walk without this curved stick which is similar to his curved back. According to Oxford Advanced Learner's Dictionary", "staff" is an old-fashioned or formal word that refers to "a long stick used as a support when walking or climbing, as a weapon or as a symbol of authority" (2005:1433). As for the sign "برطم" /barttam/, it is used in CEA to show how angry a person is. It is a symbolic sign for the old man's anger and disapproval of something. The translation of this sign into "rant" reflects that the old man's loud and angry comments continue for some time.

Cooperson achieves semiotic equivalence in three cases out of four. He uses some suitable linguistic equivalents for the Egyptian Arabic signs used in this extract. "Poking" is used as an equivalent sign for "يزغدها". However, the translation of the sign /buz 'ukazuh/ as "staff" ignores the part in the stick which is used to poke the girl with. It seems that the ST author uses the word /buz/ as he wants the readers to imagine the scene. Accordingly, the deletion of this word in the translation results in the loss of some aspect of meaning. Finally, adding "launched into" delivers the correct meaning of the man's continuous angry comments.

\section{Extract 7:}

\begin{tabular}{|c|c|}
\hline ST & 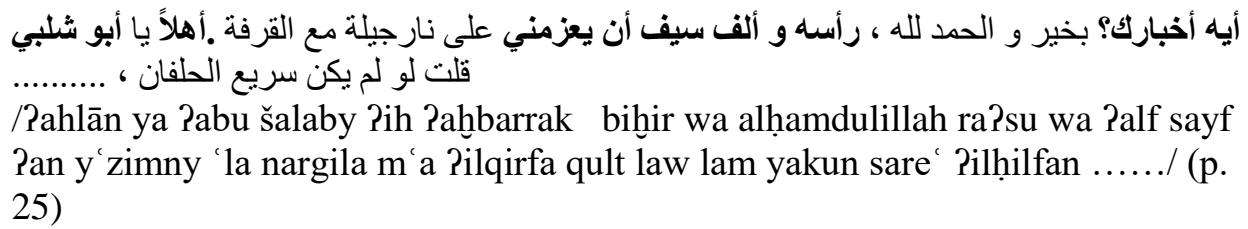 \\
\hline TT & $\begin{array}{l}\text { "Hello, Ibn Shalaby! How's it going?" } \\
\text { I told him I was fine, and he swore that wild horses couldn't stop him from } \\
\text { treating me to a water pipe filled with cinnamon tobacco. I replied that since he } \\
\text { has sworn an oath, I had better accept. (p. 21) }\end{array}$ \\
\hline
\end{tabular}


Mohamed Tohamy

\begin{tabular}{|c|c|c|c|c|c|c|}
\hline \multirow[t]{2}{*}{ Representamen (ST sign) } & \multicolumn{5}{|c|}{$\begin{array}{l}\text { Object: processing } \\
\text { representamen by translator }\end{array}$} & \multirow[t]{2}{*}{$\begin{array}{l}\text { Interpretant (TT } \\
\text { sign) }\end{array}$} \\
\hline & 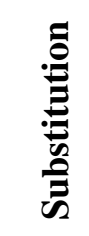 & : & 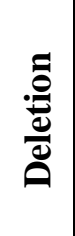 & 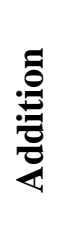 & 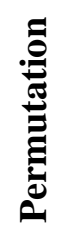 & \\
\hline \multirow{2}{*}{ 1- Pabu šalaby } & + & - & + & - & + & \multirow{2}{*}{ Ibn Shalaby } \\
\hline & \multicolumn{5}{|c|}{$\begin{array}{c}\text { someone whose (father) is } \\
\text { named Shalaby }\end{array}$} & \\
\hline \multirow{2}{*}{ 2- Pih Pahbarrak } & + & - & + & + & + & \multirow{2}{*}{ How's it going? } \\
\hline & \multicolumn{5}{|c|}{ greeting, social interaction } & \\
\hline \multirow[b]{2}{*}{ 3- ra?su wa Palf sayf } & + & - & + & + & - & \multirow{2}{*}{$\begin{array}{l}\text { wild horses couldn't } \\
\text { stop him }\end{array}$} \\
\hline & \multicolumn{5}{|c|}{$\begin{array}{l}\text { someone insists on doing } \\
\text { something }\end{array}$} & \\
\hline \multirow[b]{2}{*}{ 4- nargila m’a Pilqirfa } & + & - & + & + & - & \multirow{2}{*}{$\begin{array}{l}\text { a waterpipe filled with } \\
\text { cinnamon tobacco }\end{array}$} \\
\hline & \multicolumn{5}{|c|}{$\begin{array}{l}\text { smoke a waterpipe and have a } \\
\text { cinnamon drink }\end{array}$} & \\
\hline \multirow{3}{*}{$\begin{array}{l}\text { 5- law lam yakun sare } \\
\text { Pilhilfan }\end{array}$} & + & - & - & + & - & \multirow{2}{*}{$\begin{array}{l}\text { since he has sworn an } \\
\text { oath, I had better } \\
\text { accept }\end{array}$} \\
\hline & \multicolumn{5}{|c|}{$\begin{array}{l}\text { someone insists on inviting } \\
\text { another by swearing }\end{array}$} & \\
\hline & \multicolumn{5}{|c|}{$\begin{array}{c}\text { Warm greeting and invitation } \\
\text { to smoke a water pipe and } \\
\text { drink cinnamon }\end{array}$} & \\
\hline
\end{tabular}

This extract is an example of a speech act of greeting and showing hospitality in a purely Egyptian way. The speaker insists on inviting Ibn Shalaby to smoke a waterpipe and have a famous Egyptian drink, cinnamon. The representamen contains a number of culture-based signs/expressions which may lose some of their connotations when translated into English. The first sign to be discussed is / Rabu šalaby/ which is rendered by Cooperson as "Ibn Shalaby". Literally / Rabu/ means "father" and / Pibn/ means "son". It seems that the translator got confused between the two signs as he does not have a background about how these signs are used in CEA. According to Amin (2013), / Rabu/ in CEA is sometimes used to mean son; so /abu yousof/ is used to call someone whose father is named Yousof (p. 27). The translator fails to render this cultural taste when he deletes the sign / $\mathrm{Pabu} /$ and substitutes it with /Pibn/. However, the translator replaces the full stop (.) in the representamen with an exclamation mark (!). In English, exclamation marks are used to 


\section{Who Sold Pickles and Sweets": A Semiotic Approach}

show strong emotions such as delight or surprise. The translator uses the exclamation mark in this situation as a paralinguistic feature to reflect the warm reception that Ibn Shalaby receives in this extract.

The linguistic sign / Pih Pahbarrak/ is used as a filler to make the dialogue friendlier. Literally, it means "What is your news?". However, in CEA it is not related to getting someone's news. It is just a way of socializing when people meet. The translator successfully processes the object of this sign and translates it as "How's it going?"

The Arabic expression /ra?su wa Palf sayf/ means that someone insists on doing something without any regression. Literally, it can be interpreted as "he can put his head under the blades of a thousand swords to achieve and get what he wants". The translator uses "wild horses couldn't stop him" as a substitution for the representamen /ra?su wa Palf sayf/. According to Macmillan Online Dictionary (2020), this spoken phrase is used for emphasizing that someone is determined to do something. It is acceptable to use a TT idiom to translate an ST one although the translation may not cause the same effect of the original because idioms often reflect the history, culture and environment of the native speaker.

The extract contains an example of the translator's misunderstanding of the ST. He understood /nargila m'a Pilqirfa/ as a sort of tobacco mixed with cinnamon. In fact, cinnamon is a known drink served in Egyptian popular cafes. Taking this background into account, this sign could be translated as "a waterpipe and a cup of cinnamon drink" rather than "a waterpipe filled with cinnamon tobacco". The translator's misprocessing of the object results in an interpretant that diverges from the representamen.

Culturally speaking, the CEA expression /law lam yakun sare Pilhilfan/ is used when we have to accept someone's offer or invitation though we are not willing to do. Literally, it can be interpreted as "if he did not swear so swiftly (I might not accept the invitation). Cooperson processes the object appropriately and renders it as "since he has sworn an oath, I had better accept". His almost literal translation of this sign makes it possible to retain the native cultural taste of the original.

In his attempt to achieve semiotic equivalence between the representamen and the interpretant in this extract, Cooperson repeatedly uses the addition and deletion techniques. In (1) he deletes / Pabu/ and added /ibn/, in (2) and (3) he deletes the whole signs (/Pih Pahbarrak/, ra?su wa Palf sayf ) and adds ones which are not lexically related to the 
original ("How's it going?", "wild horses couldn't stop him"), and in (5) he adds the clause "I had better accept".

\section{Extract 8:}

\begin{tabular}{|c|c|}
\hline ST & $\begin{array}{l}\qquad \text { و لحق بي هامساً في تودد كبير : ( ما أوصيش سعادتك .. لو خاتم بفص للأكرى ... (wa lahiq bi hamisan fi tawadud kabir : mawṣ̄šs sa addtak .. law hatim } \\
\text { bifaṣ lilzikra../ (p. 29) }\end{array}$ \\
\hline $\mathbf{T T}$ & $\begin{array}{l}\text { then caught up with me, whispering as if we were old friends, "If it's not } \\
\text { too much trouble, sir, could you save me something, even just a ring } \\
\text { with a gemstone in it, as a souvenir?" (p. 26) }\end{array}$ \\
\hline
\end{tabular}

\begin{tabular}{|c|c|c|c|c|c|c|}
\hline \multirow[t]{2}{*}{ Representamen (ST sign) } & \multicolumn{5}{|c|}{$\begin{array}{l}\text { Object: processing } \\
\text { representamen by translator }\end{array}$} & \multirow[t]{2}{*}{ Interpretant (TT sign) } \\
\hline & & 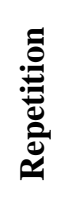 & :气 & : & 胥 & \\
\hline \multirow{3}{*}{ mawșī̌š sa'addtak } & + & - & + & + & + & \multirow{2}{*}{$\begin{array}{l}\text { If it's not too much } \\
\text { trouble, sir, could you } \\
\text { save me something }\end{array}$} \\
\hline & \multicolumn{5}{|c|}{ request } & \\
\hline & \multicolumn{5}{|c|}{$\begin{array}{l}\text { I politely request a ring with a } \\
\text { gemstone as a souvenir. }\end{array}$} & \\
\hline
\end{tabular}

This extract is a speech act, a request, coded in CEA. The addresser, who occupies a lower position on the power hierarchy, is politely requesting a souvenir from the addressee who is a superordinate, or higher on power hierarchy. That is why the addresser initiates his request with /mawșīš sa'addtak/ which, in the Egyptian culture, is an iconic sign for reminding others of what they may do for us. Literally, it can be translated as "I do not recommend you do it", but this is not what it means. The translator processed the representamen appropriately and understood it to be a request. Thus the interpretant, "if it is not too much trouble", yields the intended meaning despite being void of ST cultural flavour. It is also noted that the negative structure in the representamen has been rendered in the form of a conditional if-clause followed by the independent clause, "could you save me something", to make the whole sentence understood as a request. To show the differing power relations between the speakers, the translator uses the sign "sir". 
Translating Culture-Specific Items in Khairy Shalaby's "The Time-Travels of the Man

\section{Who Sold Pickles and Sweets": A Semiotic Approach}

Cultural semiotic equivalence could not be achieved in this extract as the translator has to delete the sign /mawșišs/, and compensate for it by adding a whole conditional sentence. Permutation is also present in this extract where the translator adds extra information, like the dependent clause "could you save me something".

Extract 9:

\begin{tabular}{|c|c|}
\hline ST & 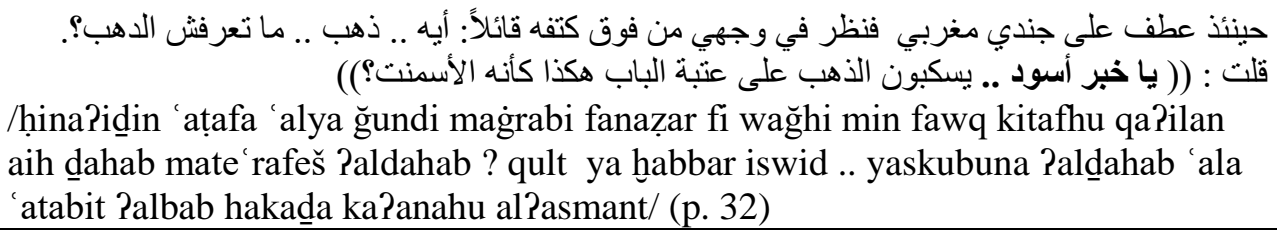 \\
\hline $\mathbf{T T}$ & $\begin{array}{l}\text { A Moroccan soldier leaned back and surveyed me over his shoulder. "It's gold. } \\
\text { Never heard of it before?" } \\
\text { "Holy cow! They pour gold out on the threshold like cement?" (p. 30) }\end{array}$ \\
\hline
\end{tabular}

\begin{tabular}{|c|c|c|c|c|c|c|}
\hline \multirow[t]{2}{*}{ Representamen (ST sign) } & \multicolumn{5}{|c|}{$\begin{array}{l}\text { Object: processing representamen } \\
\text { by translator }\end{array}$} & \multirow[t]{2}{*}{ Interpretant (TT sign) } \\
\hline & 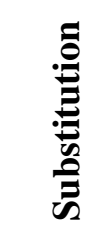 & 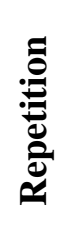 & 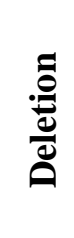 & 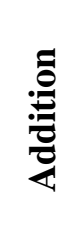 & 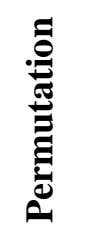 & \\
\hline \multirow{2}{*}{ ya habbar iswid .. } & + & - & + & + & + & \multirow{2}{*}{ Holy cow! } \\
\hline & \multicolumn{5}{|c|}{$\begin{array}{l}\text { It is great astonishment to see gold } \\
\text { poured on the ground. }\end{array}$} & \\
\hline
\end{tabular}

In his time travels, Ibn Shalaby found himself in the era of the Fatimid State that is known for its luxury and opulence. Seeing gold being poured on the threshold like cement, Ibn Shalaby exclaimed surprisingly /ya habbar iswid ../, which is a symbolic sign for bad news. It shows that it is unbelievable to pour gold on the ground. It can be literally translated as "What a black piece of news!", which is associated with the black colour and its negative connotations in Egyptian culture. The translator uses the expression "Holy cow!" which is an informal idiom used as an interjection to express surprise or excitement (MerriamWebster, 2020). Semiotically speaking, semiotic equivalence is achieved in this example though it loses some of its cultural connotations. The translator uses three transformation strategies in his attempt to find a semiotically equivalent translation for this expression. Like the previous example, he deletes the whole ST sign and adds a TT one which is 
lexically unrelated to the ST. To highlight the feeling of astonishment, the translator uses an exclamation mark instead of the dots used in the ST.

\section{Extract 10:}

\begin{tabular}{|c|c|}
\hline ST & 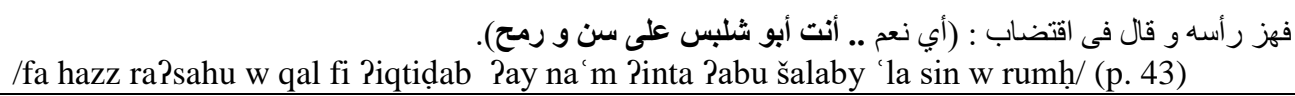 \\
\hline TT & He nodded and said curtly, "Indeed we do. You're the famous Ibn Shalaby." (p. 42) \\
\hline
\end{tabular}

\begin{tabular}{|c|c|c|c|c|c|c|}
\hline \multirow[t]{2}{*}{ Representamen (ST sign) } & \multicolumn{5}{|c|}{$\begin{array}{c}\text { Object: processing representamen by } \\
\text { translator }\end{array}$} & \multirow[t]{2}{*}{ Interpretant (TT sign) } \\
\hline & 莞 & لَّ & & 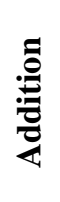 & : & \\
\hline \multirow{2}{*}{ /'la sin w rumḥ/ } & + & - & + & + & - & \multirow{2}{*}{ famous } \\
\hline & \multicolumn{5}{|c|}{ well-known, dignified, respected, great } & \\
\hline
\end{tabular}

The representamen in this extract can be interpreted as "Ibn Shalaby, the protagonist of the novel, is a well-known, respected and dignified person". In the Egyptian culture, the object of this extract means that people sometimes glorify and appreciate each other trying to break the ice and create a sociable atmosphere when they use expressions such as /'la sin w rumbl/ to praise someone. The ST sign contains two elements /Pinta Pabu šalaby/and the very colloquial Egyptian expression /'la sin w rumh/. This element is not translated literally in the TT (i.e. you are on the spearhead). Taymour Pasha (2016, p. 57) explains that this is a metaphoric expression used in CEA to refer to dignity, greatness, respect and prominent status in society. The original expression " " سين الرمح" /sin

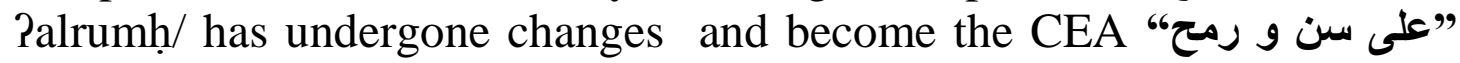
/ la sin w rumh/. The translator introduces only one aspect of the meaning of the representamen when he renders it as "the famous". He misprocesses the object as he interprets it as just "the famous" ignoring other connotations of the sign. Semiotic equivalence is not achieved in this extract as the translator deletes the whole ST sign and adds one that is not semiotically related to the ST. 
Translating Culture-Specific Items in Khairy Shalaby's "The Time-Travels of the Man Who Sold Pickles and Sweets": A Semiotic Approach

\section{Conclusion}

This study focuses on culture-specific items in Michael Cooperson's translation of Khairy Shalaby's novel The Time-Travels of the Man Who Sold Pickles and Sweets. The novel is immersed in Egyptian culture and history; therefore, it arouses linguistic and cultural difficulties for the translator. Ten extracts containing 27 culture-specific items are studied and analyzed using Peirce's three-dimensional model as developed by Torop (2008) and revised by the author of the present study. The two research questions that are posed on the study revolve around whether or not the translator is successful in delivering the semiotic representation of the ST items, and the extent to which the translator's cultural background affects his ability to transmit the semiotic connotations of the ST items. It has been found that out of 27 culture-specific items, the translator fails to deliver the semiotic representation of 15 , which may result in the loss of some aspects of the meaning intended by the ST author. Being a nonnative, the translator lacks the appropriate cultural semiotic background to assume the task of translating a literary work that is abundant in culture-specific items. To process the representamen (ST sign), the translator resorts to some transformation strategies, particularly addition and deletion, before delivering the interpretant (TT sign). These strategies are extensively used when the translator finds it difficult to render a semiotically equivalent sign. The results also show that some items are ignored, or deleted, when the translator fails to process the object using his own cultural background. The permutation process is rarely used by the translator although it could have been useful if the translator added some metatextual elements in the form of footnotes or parenthetical information to compensate for the absence of equivalent signs in the TT.

Integration of semiotic models in translation studies widens the boarders of appropriate research methodologies that are adopted when the cultural component of a translation is analyzed. As Sutiste and Torop (2008) put it, semiotranslation expands "the possibilities of methodological synthesis between translation studies and semiotics" (p. 203). 


\section{Mohamed Tohamy}

\section{References}

Amin, A. (2013). قاموس العادات والثقاليب والتعابير الدصرية [Dictionary of Egyptian Habits, Traditions, and Expressions]. Cairo: Hindawi Foundation for Education /Routledge.

Cooperson, M. (2010). (Trans.) The Time-Travels of the Man Who Sold Pickles and Sweets. Cairo: American University in Cairo Press.

Delabastita, D. (1993). There's a Double Tongue - An investigation into the translation of Shakespeare's wordplay, with special reference to Hamlet. Amsterdam and Atlanta GA: Rodopi.

Delabastita, D. (2008). Shakespeare in translation: A bird's eye view of problems and perspectives. Ilha do Desterro A Journal of English Language Literatures in English and Cultural Studies. doi: $10.5007 / 2175-8026.2003 \mathrm{n} 45 \mathrm{p} 103$

Dusi, N. (2015). Intersemiotic translation: Theories, problems, analysis. Semiotica (206). pp. 181-205. doi: 10.1515/sem-2015-0018

Eco, U., \& Nergaard S. (2001/1998). Semiotic approaches. In M. Baker (Ed.), Routledge encyclopedia of translation, (pp. 218-222). London: Routledge.

Elleström, L. (2014). Material and mental representation: Pierce adapted to the study of media and arts. The American Journal of Semiotics, 30(1-2), $83-138$.

Gorlée, D. (1994). Semiotics and The Problem of Translation. With Special Reference to the Semiotics of Charles S. Peirce. Amsterdam-Atlanta GA: Rodopi.

Gorlée, D. (2004). On Translating Signs. Exploring Text and SemioTranslation. (Approaches to Translation Studies 24.) NewyorAmsterdam: Rodopi.

Gottlieb, H. (1997). Subtitles, Translation and Idioms. Copenhagen: University of Copenhagen.

Jackendoff, R. (1990). Semantic Structure. Cambridge, MA: The MIT Press.

Jakobson, R. (1959). On linguistic aspects of translation. In R.A. Brower (Ed.), On translation (pp. 232-239). Cambridge, MA: Harvard University Press.

Kooij, J. (1997). Ambiguity in Natural Language: An Investigation of Certain Problems in its Linguistic Description. Amsterdam: North-Holland Pub. Co.

Kourdis, E. (2012). Semantic isotopies in interlingual translation. Towards a cultural approach. Gramma (20):105-116.

Kourdis, E. (2015). Semiotics of translation: An interdisciplinary approach to translation. In P. P. Trifonas (Ed.), International Handbook of Semiotics. Toronto: Springer. doi: 10.1007/978-94-017-9404-6_13

Kurniasih, N., Nuriman, H., \& Jaelani, J. (2019). A verbal-visual intersemiotic translation model of advertisement slogans. Journal of ILMU Komunikasi, 16(1), 1-18. 
Translating Culture-Specific Items in Khairy Shalaby's "The Time-Travels of the Man Who Sold Pickles and Sweets": A Semiotic Approach

Mostafa, E. (2019). (In Arabic) The great narrator Khairy Shalaby: I incite youth to read one thousand pages before writing one. ALdostor Newspaper. Retrieved 21, August 2020. https://www.dostor.org/2560034

Newmark, P. (1988). A Textbook of Translation. New York: Prentice Hall.

Nöth, W. (2012). Translation and semiotic mediation. Sign Systems Studies 40(3/4). pp. 279-298.

Parlog, A. (2019). Intersemiotic Translation: Literary and linguistic multimodality. Palgrave: Macmillan.

Peirce, C. (1931-58) Collected Papers (8 vols: vol. 1, Principles of Philosophy, ed. Charles Hartshorne and Paul Weiss. Cambridge, MA: Harvard University Press.

Peirce, C. (1992). The Essential Peirce. Selected Philosophical Writings. Volume1 (1867-1893). Nathan Houser and Christian Kloesel (eds.). Bloomington: Indiana University Press.

Perez-Gonzalez, L. (2014). Multimodality in translation and interpreting studies. In Sandra Bermann \& Catherine Porter (eds.), A companion to Translation Studies (pp. 119-131). Chichester: Wiley-Blackwell.

Petrilli, S. (2013). Translation as listening to the other. A semioethic approach. Acta Translatologica Helsingiensia (2):116-145.

Remael, A. (2001). Some thoughts on the study of multimodal and multimedia translation. In Yves Gambier \& Henrik Gottlieb (eds.), (Multi) Media Translation: Concepts, Practices and Research (pp. 13-22). Amsterdam: John Benjamins.

Shalaby, K. (1991). رحلات الطرشجي الحلوجي [The Time-Travels of the Man Who Sold Pickles and Sweets]. Cairo: Madbouly Bookshop and Printing House.

Siskin, J. (1987). A medieval semiotics of translation. Semiotics (36). pp. 129-142.

Spiro, S. (1991). English-Arabic Vocabulary of the Modern and Colloquial Arabic of Egypt. Cairo: Al-mokattam Printing Office.

Sutiste, E., \& Torop, P. (2007). Processual boundaries of translation: Semiotics and translation studies. Semiotica, 163(1/4), 187-207. Retrieved from https://doi.org/10.1515/SEM.2007.011

Taymour Basha, A. (2016). الكنايات العامية [Colloquial Metaphors]. Cairo: Hindawi Foundation for Education and Culture.

Torop, P. (2000). Towards the semiotics of translation. Semiotica, 128(3/4). Pp. 597-609.

Torop, P. (2002). Translation as translating as culture. Sign Systems Studies, 30(2). Pp. 593-605.

Torop, P. (2008). Translation and semiotics. Sign Systems Studies, 36(2). Pp. 253-257.

Wassef, H. (2004). Food habits of the Egyptians: Newly emerging trends. Eastern Mediterranean Health Journal, 10(6), 898-915.

Wehmeier, S. (2005). Oxford Advanced Learner's Dictionary. Seventh Edition. Oxford University Press. 


\section{Mohamed Tohamy}

\section{LIST OF TRANSLAITRATION SYMBOLS}

The following symbols, adopted from Rietbroek (2010), are used to represent

Arabic consonants and vowels for the transliteration of the ST.

\begin{tabular}{|c|c|c|c|c|c|}
\hline 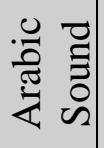 & $\begin{array}{l}\text { ठ } \\
\text { है } \\
\text { के }\end{array}$ & Description & 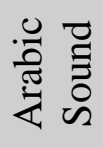 & 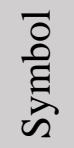 & Description \\
\hline 1 & $\begin{array}{l}\mathrm{a} \\
\overline{\mathrm{a}}\end{array}$ & $\begin{array}{l}\text { Front, open, spread, short } \\
\text { Back, open, neutral, long }\end{array}$ & $\varepsilon$ & ' & $\begin{array}{c}\text { Pharyngeal, fricative, } \\
\text { voiced }\end{array}$ \\
\hline ب & $b$ & Bilabial, stop, voiced & $\dot{\varepsilon}$ & $\dot{\mathrm{g}}$ & Uvular, fricative, voiced \\
\hline$ت$ & $\mathrm{t}$ & $\begin{array}{l}\text { Alveodental, stop, } \\
\text { voiceless }\end{array}$ & ف & $\mathrm{f}$ & $\begin{array}{c}\text { Labiodental, fricative, } \\
\text { voiceless }\end{array}$ \\
\hline$\dot{H}$ & $\underline{\mathrm{t}}$ & $\begin{array}{l}\text { Interdental, fricative, } \\
\text { voiceless }\end{array}$ & ق & q & Uvular, stop, voiceless \\
\hline ج & $\hat{\mathrm{g}}$ & Velar, stop, voiced & ك & $\mathrm{k}$ & Velar, stop, voiceless \\
\hline$\tau$ & ha & $\begin{array}{c}\text { Pharyngeal, fricative, } \\
\text { voiceless }\end{array}$ & J & 1 & $\begin{array}{c}\text { Alveodental, lateral, } \\
\text { voiced }\end{array}$ \\
\hline$\dot{\tau}$ & $\underline{\mathrm{h}}$ & Uvular, fricative, voiced & s & $\mathrm{m}$ & Bilabial, nasal, voiced \\
\hline د & d & Alveodental, stop, voiced & ن ن & $\mathrm{n}$ & Alveodental, nasal, voiced \\
\hline$\dot{~}$ & $\underline{\mathrm{d}}$ & $\begin{array}{c}\text { Interdental, fricative, } \\
\text { voiced }\end{array}$ & $ه$ & $\mathrm{~h}$ & Glottal, fricative, voiceless \\
\hline J & $\mathrm{r}$ & Alveodental, trill, voiced & 9 & $\begin{array}{l}\mathrm{W} \\
\overline{\mathrm{u}}\end{array}$ & $\begin{array}{c}\text { Labiovelar, glide, voiced } \\
\text { Back, close, close } \\
\text { rounded, long } \\
\end{array}$ \\
\hline j & $\mathrm{z}$ & $\begin{array}{c}\text { Alveodental, fricative, } \\
\text { voiced }\end{array}$ & ي & $\begin{array}{l}\mathrm{y} \\
\overline{1}\end{array}$ & $\begin{array}{l}\text { Palatal, glide, voiced } \\
\text { Front, close, spread, long }\end{array}$ \\
\hline 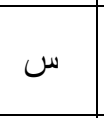 & $\mathrm{s}$ & $\begin{array}{c}\text { Alveodental, fricative, } \\
\text { voiceless }\end{array}$ & 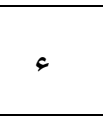 & $?$ & Glottal, stop, voiceless \\
\hline 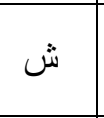 & $\check{\mathrm{S}}$ & $\begin{array}{c}\text { Alveopalatal, fricative, } \\
\text { voiceless }\end{array}$ & 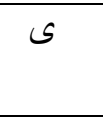 & $\overline{\mathrm{a}}$ & Back, open, neutral, long \\
\hline ص ص & Ș & $\begin{array}{l}\text { Alveodental, emphatic } \\
\text { fricative, voiceless }\end{array}$ & 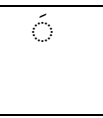 & $\mathrm{a}$ & Front, open, spread, short \\
\hline 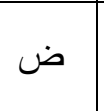 & d & $\begin{array}{l}\text { Alveodental, emphatic } \\
\text { stop, voiced }\end{array}$ & 9 & $\mathrm{i}$ & $\begin{array}{l}\text { Front, half-close, spread, } \\
\text { short }\end{array}$ \\
\hline b & $\mathrm{t}$ & $\begin{array}{l}\text { Alveodental, emphatic } \\
\text { stop, voiceless }\end{array}$ & 8 & $\mathrm{u}$ & $\begin{array}{l}\text { Back, half-close, close- } \\
\text { rounded, short }\end{array}$ \\
\hline ظ & Z & $\begin{array}{l}\text { Interdental, emphatic } \\
\text { fricative, voiced }\end{array}$ & & & \\
\hline
\end{tabular}

